Review

\title{
Potential Use of Spin Traps to Control ROS in Antipollution Cosmetics-A Review
}

\author{
Prashant D. Sawant \\ R\&D, Intraceuticals Pty Ltd, Melbourne 3137, Australia; Prashant.sawant@intraceuticals.com.au; \\ Tel.: + 61-3-9751-8000
}

Received: 19 December 2017; Accepted: 5 January 2018; Published: 7 January 2018

\begin{abstract}
Pollution from air and sunlight has adverse effects on human health, particularly skin health. It creates oxidative stress, which results in skin diseases, including skin cancer and aging. Different types of antioxidants are used as preventative actives in skin-care products. However, they have some limitations as they also scavenge oxygen. Recently, spin traps are being explored to trap free radicals before these radicals generating more free radicals (cascading effect) and not the oxygen molecules. However, not all spin traps can be used in the topical cosmetic skin-care products due to their toxicity and regulatory issues. The present review focuses on the different pathways of reactive oxygen species (ROS) generation due to pollution and the potential use of spin traps in anti-pollution cosmetics to control ROS.
\end{abstract}

Keywords: pollution; cosmetics; skin-care; ROS; oxidative stress; antioxidants; spin traps; blue light

\section{Introduction}

The World Health Organization (WHO) has recognized the urban pollution as one of the most important environmental issues in the world. Over $99 \%$ of the urban population in Asia is regularly exposed to concentrations of air pollutants that are above the WHO recommendation level. According to the latest urban air quality database [1], more than 100,000 inhabitants in $98 \%$ of cities in low- and middle-income countries do not live in areas with good or healthy quality air (as per WHO air quality guidelines). On the contrary, high-income countries are improving their air quality.

Air pollution is comprised of various particulate matters (PMs) that can cause skin diseases, cancer, pulmonary, and cardiovascular diseases [2-4]. The increased ambient PM from industrialization and urbanization is highly associated with morbidity and mortality worldwide [2].

Free radicals or reactive chemical species exhibit a single unpaired electron in an outer orbit to form the unstable configuration creating energy and releasing it through reactions with adjacent molecules, such as proteins, lipids, carbohydrates, and nucleic acids [5]. The major members of the reactive oxygen species (ROS) include free radicals like $\mathrm{O} \bullet{ }_{2}, \mathrm{OH} \bullet$ and non-radicals like $\mathrm{H}_{2} \mathrm{O}_{2}$ and ${ }^{1} \mathrm{O}_{2}$ (Table 1). The ROS can be harmful or beneficial in biological systems depending on its surrounding environment and exposures [6,7].

Nanosized particles from traffic sources are the most harmful components of ambient PM [8] because of oxidative stress due to their small size and large surface per unit mass, and are highly reactive towards biological surfaces and structures [9]. Additionally, nanoparticles can carry organic chemicals and metals to mitochondria and generate ROS [10]. Additionally, Polycyclic Aromatic Hydrocarbons (PAHs) adsorbed on the surface of airborne PM [11] can activate xenobiotic metabolism to convert PAHs into quinones and producing ROS [12]. 
Table 1. Some examples of molecules and corresponding free radicals.

\begin{tabular}{|c|c|c|}
\hline Molecule & Symbol & Free Radical Structure \\
\hline Oxygen & $\mathrm{O}_{2}$ & \\
\hline Hydrogen Peroxide & $\mathrm{H}_{2} \mathrm{O}_{2}$ & $: \mathrm{H}$ \\
\hline Superoxide anion & $\bullet \mathrm{O}^{-}{ }_{2}$ & \\
\hline Peroxide & $\cdot \mathrm{O}^{-2}{ }_{2}$ & \\
\hline Hydroxyl Radical & $\bullet \mathrm{OH}$ & \\
\hline Hydroxyl ion & $\mathrm{OH}^{-}$ & \\
\hline
\end{tabular}

Antioxidants are often used to reduce the effect of oxidative stress. Two types of antioxidants that can help scavenge ROS [5] are (i) enzymatic antioxidants such as superoxide dismutase (SOD), catalase (CAT), ascorbate peroxidase (APX), guaiacol peroxidase (GPX), glutathione reductase (GR), monodehydroascorbate reductase (MDHAR), and dehydroascorbate reductase (DHAR); and (ii) non-enzymatic antioxidants such as ascorbic acid (AA), reduced glutathione (GSH), $\alpha$-tocopherol, carotenoids, flavonoids, and the osmolyte proline. A co-factor is an ion or a molecule that binds to the catalytic site of an apoenzyme rendering it active. In addition to antioxidants, co-factors [5] such as zinc also play an important role in the free radical induced oxidative damage. It is five to six times more concentrated in the epidermis than the dermis. Zinc is an essential element of more than 200 metalloenzymes including the antioxidant enzyme and CuZnSOD [13]. Topical divalent zinc provides antioxidant photoprotection for skin either by replacing redox active molecules such as iron and copper at critical sites in cell membranes and proteins or by inducing the synthesis of metallothionein like sulfhydryl-rich proteins that protect against free radicals [13].

The conventional antioxidants react with free radicals to convert the ROS into water. However, antioxidants may also contribute to hypoxia in deep tissue by indiscriminately converting both normal oxygen and ROS molecules to water [14]. On the other hand, spin traps have the ability to scavenge or stabilize free radicals before their deterioration and help reduce their cascade effect on other molecules to generate more free radicals. Spin traps can selectively trap ROS as opposed to antioxidants [15].

The present review discusses ROS and oxidative stress pathways arising due to pollution, the potential use of spin traps against ROS and oxidative stress, and their limitations.

\section{Pollution and Its Effect on the Skin}

The following are four mechanisms [16] by which ambient air pollutants cause adverse effects on skin health: (i) generation of free radicals, (ii) induction of inflammatory cascade and subsequent impairment of skin barrier, (iii) activation of the aryl hydrocarbon receptor (AhR) and (iv) alterations to skin microflora. The effect of pollutant on skin indications are summarized in Table 2.

Ambient PM can penetrate the skin either through hair follicles or trans-epidermally [17], and PM-bound PAHs generate ROS $[18,19]$. The long-term exposure to air pollution can lead to extrinsic skin aging through oxidative stress generated by the particles themselves and/or by associated PAHs. Moreover, PMs have been found to disrupt stratum corneum integrity by 2 -fold and mildly damaging tight junctions [20]. Additionally, an increase in soot (per $0.5 \times 10^{-5} / \mathrm{m}$ ) and particles from traffic (per $475 \mathrm{~kg} /$ year $/ \mathrm{km}^{2}$ ) has been associated with $20 \%$ more pigment spots on the forehead and cheeks [21]. 
Table 2. Pollution and skin diseases.

\begin{tabular}{ccc}
\hline No. & Pollution Type & Skin Indications \\
\hline 1 & Ultraviolet radiation & Extrinsic skin aging and skin cancers \\
\hline 2 & Cigarette smoke & $\begin{array}{c}\text { Premature aging, psoriasis, acne and skin } \\
\text { cancers, atopic dermatitis and eczema }\end{array}$ \\
\hline 3 & Polyaromatic hydrocarbons & $\begin{array}{r}\text { Extrinsic skin aging, pigmentation, cancers } \\
\text { and acneiform eruptions }\end{array}$ \\
\hline 4 & Volatile organic compounds & Atopic Dermatitis \\
\hline
\end{tabular}

PM induces oxidative stress through the production of ROS and secretion of pro-inflammatory cytokines such as Tumor necrosis factor (TNF)- $\alpha$, Interleukin (IL)- $1 \alpha$ and IL-8 [4]. The increased production of ROS such as superoxide and hydroxyl radical by PM exposure increases matrix metalloproteinases (MMPs) such as MMP-1, MMP-2 and MMP-9. MMPs are responsible of the degradation of collagen and lead to the increase in inflammatory skin diseases and skin aging [4]. In addition, environmental cigarette smoke, which is well known as an oxidizing agent, is responsible for androgenetic alopecia (AGA). The ultrafine particles including black carbon and PAHs enhance the incidence of skin cancer. Overall, increased PM levels are responsible for the development of various skin diseases via the regulation of oxidative stress and inflammatory cytokines. Antioxidant and anti-inflammatory drugs may be useful for treating PM-induced skin diseases.

The onset of systemic lupus erythematosus (SLE), an immune-complex-mediated multi-systemic autoimmune condition, can be flared by various environmental factors such as cigarette smoke, alcohol, occupationally- and non-occupationally- related chemicals, ultraviolet (UV) light, infections, etc. [22].

Sensitive skin is induced by various environmental factors such as UV light, cold, heat and air pollution. The activation of cutaneous endothelin receptors and transient receptor potential (TRP) channels represent a mechanism by which external environmental stimuli are transferred to individuals with sensitive skin [23]. Additionally, UV irradiations upregulate proinflammatory lipids including lysophosphatidic acids (LPA) such as LPA 18:1 [24]. These upregulated proinflammatory lipids are agonists of TRPV1 (transient receptor potential cation channel subfamily V member 1 or the capsaicin receptor or the vanilloid receptor 1) in the skin [24]. TRPV1 contributes to thermal hyperalgesia and mechanical allodynia and trigger the sensation of pain [24]. Toll-like receptors (TLRs) are cellular sensors that recognize pathogens and can be expressed on various cell types including keratinocytes, Langerhans cells, mast cells, and fibroblasts in the skin. Upon stimulation with exogenous or endogenous ligands, TLR3 cells are intimately involved in the pathogenesis of infectious or inflammatory skin diseases such as viral infections or allergic and irritant contact dermatitis, and itching sensations in the skin [25].

Atopic dermatitis (AD) is a chronic skin disorder which is characterized by pruritus and recurrent eczematous lesions that are accompanied by T-helper (Th)2-dominated inflammation. AD is characterized by complex interactions between genetic and environmental factors, such as skin barrier dysfunctions, allergy/immunity, and pruritus. Filaggrin is one of the key proteins involved in skin barrier function. Th2 cells produce interleukin (IL)-31 which can provoke pruritus and other Th2 cytokines can decrease filaggrin expression by keratinocytes. AD can be treated by newly developed drug, Dupilumab (as a post treatment and not as preventative measure), which can bind to IL-4 receptor $\alpha$ and inhibit downstream signaling induced by IL-4 and IL-13 [26].

UV irradiation is one of main environment pollutants that can cause human carcinogens $[27,28]$. The UV radiation is mainly composed of UV-A $(\lambda=320-400 \mathrm{~nm}), \mathrm{UV}-\mathrm{B}(\lambda=280-320 \mathrm{~nm})$, and UV-C $(\lambda=200-280 \mathrm{~nm})$. UV-C is absorbed by oxygen and ozone in the Earth's atmosphere and does not have any significant impact on the skin [27]. However, the longer wavelength, UV-B and UV-A radiations, have significant effects on the biota. Moreover, $98.7 \%$ of the UV radiation that reaches the Earth's surface is UV-A [29,30]. UV irradiations are responsible for melanoma formation [31]. The DNA 
damaging, carcinogenic, inflammatory, and immunosuppressive properties of UV radiations contribute to initiation, progression, and metastasis of primary melanoma [32]. The changes in ROS signaling pathways have the damaging action of UV-A and UV-B irradiations on the skin [33]. Moreover, the overproduction of ROS may stimulate malignant transformation to melanoma.

UV-A light can deeply penetrate into the skin [34,35] generating ROS that damages DNA leading to $92 \%$ of malignant melanoma [36]. On the contrary, UV-B light, that has a shorter wavelength than UV-A light, causes sunburn [37], induces DNA damage leading to the apoptosis of keratinocytes [38]. Therefore, UV-B light affects the skin directly compared to UV-A light and is responsible for $8 \%$ of total melanoma production [36]. Mechanistically, the UV-B light exposure results in (i) the formation of covalent linkages between pairs of thymine and cytosine bases in DNA, (ii) the formation of pyrimidine (cyclobutane) dimers and (iii) the excitation of DNA of the skin cells. Additionally, the DNA polymerase incorporates an incorrect base opposite to an abnormal base leading to a DNA mutation during the replication process, which, in turn, can cause skin cancers. In addition to the DNA mutation, some of the major side products such as 6-4 photoproducts (6-4 PPs) pyrimidine adducts and Dewar valence isomers are also formed by the photoisomerization of 6-4 PPs due to exposure of the skin cells to UV-B light (>290 nm) [39-44]. Most of these genetic lesions are generally corrected by nucleotide excision repair. The genetic information may be permanently mutated if nucleotide excision repair dies not occur.

After UV-A irradiation absorption, endogenous photosensitizes such as flavins [45], NADH/ NADPH [46], urocanic acid [47], and some sterols [48] present in tissue are converted to their long-lived triplet state, which in turn can transfer energy to oxygen molecules to form an energetically excited and highly reactive singlet oxygen. Additionally, a novel class of UV-A photo-sensitizers comprised of skin biomolecules based on 3-hydroxypyridine derivatives such as enzymatic collagen cross-links, B6 vitamin, and glycation end products in chronologically aged skin are capable of skin photooxidative damage [49]. UV-A-irradiated cultured human melanocytes can be photosensitized by chromophores such as pheomelanin and/or melanin intermediates [50]. In addition, UV-B natural chromophores may exhibit similar phototoxic properties. UV-B-sensitized tryptophan produces singlet oxygen $\left({ }^{1} \mathrm{O}_{2}\right)$ and superoxide radicals $\left(\mathrm{O}^{2-}\right.$.), and these reactive forms of oxygen may contribute to membrane-, cytoplasm- and DNA-damaging effects [51]. Singlet oxygen, hydroxyl radical and hydrogen peroxide are ROS that can also produce oxidative stress in cells and organisms [52]. Oxidative stress is the imbalance between ROS production and a biological system's ability to detoxify these reactive intermediates. The oxidative stress is considered as a critical pathophysiological mechanism in cancererogenesis [53]. Reactive chemical species can reach DNA by diffusion and the resultant bimolecular reaction will damage the DNA [54]. Singlet oxygen interacts preferentially with guanine to produce 8-oxo-7,8-dihydroguanine after losing two electrons. Additional removal of two electrons from 8-oxo-7,8-dihydroguanine can yield highly mutagenic spiroiminodi-hydantoin ( $\mathrm{Sp}$ ) $\mathrm{R}$ and $\mathrm{S}$ stereoisomers that are capable of causing $G \rightarrow T$ and $G \rightarrow C$ conversions, and, in turn, this may initiate cancer $[52,55]$.

Typical levels of ozone that are recorded in urban environments are in the range of 0.2 to 1.2 ppm [56,57]. This century will see an increase in ozone levels, which will have adverse effects on skin [58].

Ozone is a potent oxidant that can react with a variety of extracellular and intracellular biomolecules [59-62] and damage the barrier function of the epidermis [61]. The cytotoxicity of ozone is due to its capability of antioxidant depletion [63-65] and its interaction with unsaturated lipids to generate damaging free radicals or toxic intermediate products [66]. Ozone exposure can influence antioxidant levels and oxidation markers in the outermost stratum corneum layer $[67,68]$. The changes in the oxidant levels and oxidation markers induce cellular stress responses in the deeper skin cells [69]. The chronic exposure of the skin to environmental stressors can overwhelm the skin's defensive system comprised of both enzymatic and non-enzymatic low molecular weight antioxidants [70], and induces persistent damage to cutaneous tissues. Therefore, antioxidants can be 
used as a defensive approach against the pollution induced oxidative stress. However, the antioxidant protection is limited by the first-pass metabolism and the lack of ability to sustain enough antioxidants in the skin. Additionally, the topical application of single antioxidants is not enough to protect the skin in a comprehensive manner; therefore, the synergistic action of diverse types (enzymatic and non-enzymatic) of antioxidants may better protect against oxidative stress. In this regard, the combination of ferulic acid with vitamin oxidants such as vitamin $C$ and vitamin $E$ has been found to provide double protection to the skin from environmentally induced oxidative stress [71,72]. These findings may be helpful to researchers to find new ways of preventing or neutralizing the toxic effects of $\mathrm{O}_{3}$ in cutaneous tissue. The exposure of normal human epidermal keratinocytes (NHEK) to ozone $(0.3 \mathrm{ppm})$ can result in an increase in protein and messenger RNA (mRNA) expression of the family of cytochrome P450 (CYP) isoforms (CYP1A1, CYP1A2 and CYP1B1). Additionally, NHEK exposure to ozone results in nuclear translocation of the aryl hydrocarbon receptor (AhR) and in phosphorylation of epidermal growth factor receptor (EGFR). Moreover, the effect of ozone on events downstream of EGFR can result in an increased activation of phosphoinositide 3-kinase and phosphorylation of protein kinase B and mitogen-activated protein kinases [73]. Acute ozone exposure depletes skin vitamins $C$ and $E$ and induces lipid peroxidation in upper epidermal layers [74]. The dramatic increase of basal and squamous cell skin cancer in the past few years has been associated with stratospheric ozone depletion caused by ozone depleting substances (ODS) of anthropogenic origin and resultant higher UV-B radiations [75].

Skin aging leads to a progressive loss of structure and function, which can be influenced by both intrinsic and extrinsic factors. Oxidative stress induced by ROS plays an important role in the aging process [76]. Mitochondria is the major source of cellular oxidative stress and causing cutaneous aging and senescence. Antioxidants are generally produced to counteract the oxidative stress. However, due to environmental stress, elevated ROS levels can overwhelm endogenous cellular antioxidant mechanisms [77]. This can lead to an imbalance in tissue oxygen homeostasis, with oxidant effects outweighing antioxidant effects, and, therefore, the cellular environment becomes oxidatively stressed [77]. Oxidation of lipids by ROS can damage cellular structures and result in premature cell death [78]. In addition, the interaction with nuclear and mitochondrial nucleic acids results in mutations that predispose them to strand breaks [78]. Extrinsic skin aging is generally influenced by environmental factors and external stressors such as UV radiation, pollution and lifestyle factors that stimulate the ROS production and oxidative stress [79].

\section{Use of Antioxidants and Some Limitations Compared to Spin Traps}

The properties of antioxidants such as preventive, radical scavenging, repair and de novo, and the adaptations are described below [14]. The first line of defensive antioxidants suppresses the formation of free radicals, but the precise mechanism and site of radical formation in vivo are not well established so far. The metal-induced decompositions of hydroperoxides and hydrogen peroxide is assumed to be one of the important sources of free radicals. Some antioxidants reduce hydroperoxides and hydrogen peroxide to alcohols and water, respectively, prior to the generation of free radicals. Enzyme antioxidants such as glutathione peroxidase, glutathione-S-transferase, phospholipid hydroperoxide glutathione peroxidase (PHGPX), and peroxidase decompose lipid hydroperoxides to corresponding alcohols. PHGPX is a unique enzyme antioxidant as it can reduce hydroperoxides of phospholipids integrated into biomembranes. Antioxidants, glutathione peroxidase and catalase reduce hydrogen peroxide to water. The second line of defensive antioxidants scavenge the active radicals to suppress chain initiation and/or break the chain propagation reactions. Endogenous radical-scavenging antioxidants can be hydrophilic and lipophilic in nature. Hydrophilic radical-scavenging antioxidants are vitamin C, uric acid, bilirubin, albumin, and thiols, while lipophilic radical-scavenging antioxidants are vitamin $\mathrm{E}$ and ubiquinol. Vitamin $\mathrm{E}$ is widely treated as the most potent radical-scavenging lipophilic antioxidant. The third line of defensive antioxidants comprised of the repair and de novo antioxidants such as proteolytic enzymes, proteinases, proteases, and peptidases that are present in 
the cytosol and in the mitochondria of mammalian cells. These antioxidants recognize, degrade and remove oxidatively modified proteins and prevent the accumulation of oxidized proteins. Additionally, the DNA repair systems play an important part of the total defense system against oxidative damage. Enzymes such as glycosylases and nucleases repair the damaged DNA. Furthermore, there is an important function called adaptation that produces the signal for the production and reactions of free radicals to induce the formation and transport of the appropriate antioxidant to the right site [80]. Antioxidants have been used to reduce the effect of oxidative stress and photoaging or repair the damaged skin. However, the efficacy of antioxidants to protect the skin is dependent on potency as well as its stability of antioxidants in the skin or in the formulation [81]. Antioxidant mixtures protect against ozone induced damage in human reconstructed skin models [82]. Recently, Valacchi et al. [83] have demonstrated that antioxidant mixtures comprised of L-ascorbic acid, alpha-tocopherol, ferulic acid, and phloretin can restrict ROS production induced by ozone exposure in a reconstructed human epidermis (RHE) model in addition to the prevention of ozone-induced oxidative damage in human keratinocytes. As discussed in the next section, spin traps do not react with unpaired electrons of oxygen and trap free radicals only. Vitamin C, which is known to be antioxidant, can also be an oxidant to form the ascorbate free radical. Spin traps do not form free radicals like Vitamin C.

\section{Spin Traps (Applications and Limitations)}

Janzen and Blackburn coined the term "spin trap" for trapping free radical intermediates [15]. The fundamental mechanism of "spin trap" action is different from traditional antioxidants such as Vitamin A or C. Spin traps are quick to trap or stabilize free radicals before deterioration of free radicals. Furthermore, they can reduce the free radical cascade effect on other molecules to generate more free radicals. Spin traps essentially scavenge the free radicals and selectively trap ROS in comparison to antioxidants. As discussed before, the antioxidants chemically react with the free radicals to convert the ROS into water to terminate the chain reaction [14]. Antioxidants might be counterproductive as they may contribute to hypoxia (lack of oxygen) in deep tissues by indiscriminately converting both normal oxygen and ROS molecules to water. On the other hand, spin traps react only with the ROS in a passive way by intercepting it before any damage is done. It can differentiate between good oxygen molecules and ROS (which are harmful).

The spin trapping technique [84] consists of using a nitrone or a nitroso compound to "trap" the initial unstable free radical as a "long-lived" nitroxide that can be observed at room temperature using conventional Electron spin resonance (ESR) spectrometric procedures. The nitrone chemical structure along with an example of nitrone, $\alpha$-phenyl-tert-butyl nitrone (PBN), is depicted in Figure 1a,b. Nitrones react with, "trap" and stabilize free radical intermediates.
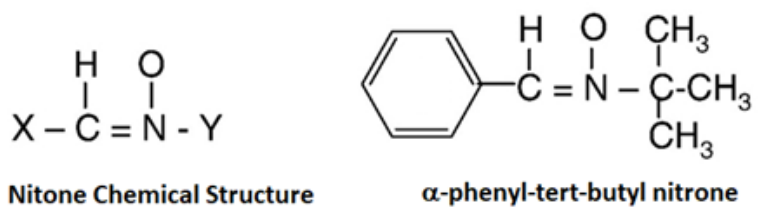

Figure 1. Chemical structures of spin trap: (a) nitrone spin trap (representative chemical structure); (b) chemical structure of $\alpha$-phenyl-tert-butyl nitrone.

Many of these intermediates exist for only a brief time and are very difficult to characterize and study. The nitrone trapping of a free radical intermediate to form a stable nitrone spin adduct is depicted in Figure 2. The reaction of the free radical species with a nitrone yields a product termed as the spin-adduct (Figure 2).

The nitroxyl free radical spin-adduct is usually much more stable than the free radical, therefore making it possible in principle to characterize the original free radical trapped using electron paramagnetic resonance methods [84,85]. In fact, Radicalomics, a cocktail of spin traps, are used 
with the EPR method to reveal the presence of free radicals in one step, their chemical nature or the site of production [85]. Some of the spin traps are listed in Table 3.

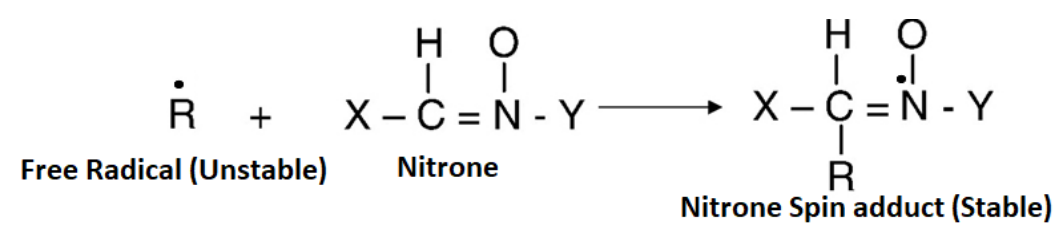

Figure 2. Spin trapping mechanism of an unstable free radical by a nitrone free radical to form a stable nitrone spin adduct.

Nitrones, particularly PBN, have been studied for anti-aging properties. PBN suppresses the amount of ROS produced in mitochondrial respiration [86-89]. With their unique actions to control ROS, spin traps also suppress pro-inflammatory conditions and destroy age-inducing free radicals in skin. Therefore, they can be utilized in skin anti-aging products, scar-reducing products, and used to treat inflammatory conditions such as rosacea and sunburn. Additionally, spin traps can control cellular oxidation states and oxidatively sensitive enzyme systems, and exhibit anti-irritant and anti-microbial properties in topical skin-care formulations. Particularly, PBN scavenges the hydroxyl free radicals generated by $\alpha$-hydroxy acids in the Fenton reaction [90].

Fuchs et al. [91,92] have studied the toxicity of different spin traps, and estimated the irritation potency (IP) based on erythematous and odematous lesions; II of spin traps estimated at $100 \mathrm{mM}$ is provided in Table 3. Based on II, authors [91] have found that the nitroxide precursors and nitrones can be classified clinically non-irritant (2,2,5,5-tetramethyl-1-dihydro-pyrrolinoxyl (PROXO), 2,2,3,4,5,5-hexamethyl-imidazoline-1-yloxyl (Imidazo), 5,5-dimethyl-1-pyrroline N-oxide (DMPO) (Table 3)) to slightly irritant (3,3,5,5-tetramethylpyrroline-N-oxide (TEMPO), 2,2,5,5-tetramethyl-3-oxazolidinoxyl (DOXO), PBN (Table 3)) as per the Draize protocol. PBN, DOXO, and TEMPO are found to be non-irritant at $10 \mathrm{mM}$; therefore, a low amount of these three spin traps can be used in cosmetic formulation to avoid toxicity. Further research may be needed to find maximum safe concentrations of these three spin traps.

Authors [91] have also found a significant increase in the trans-epidermal water loss values by $100 \mathrm{mM}$ of TEMPO, DOXO and PBN and 2,2,6,6-tetramethyl-1-hydroxypiperidine (TOLH), hydroxylamine-TEMPO and its major skin metabolite did not cause skin irritation. The nitroxide irritancy potency is found to be TEMPO $>$ DOXO $>$ Imidazo $=$ PROXO. This irritancy potency is further found to be in inverse order (Imidazo $=\mathrm{PROXO}>\mathrm{DOXO}>\mathrm{TEMPO}$ ) of nitroxide biostability in murine and human skin [91].

Additionally, nitroxides and nitrones did not show the sensitizing effect as per the Magnusson and Kligman test. Therefore, the nitroxide precursors and nitrones tested have exhibited a low potential of acute skin intolerance. Janzen et al. [92] found that the lethal dose of PBN was found to be approximately $100 \mathrm{mg} / 100 \mathrm{~g}$ bodyweight $(0.564 \mathrm{mmol} / 100 \mathrm{~g})$, suggesting that PBN is non-toxic. DMPO was found to be the least toxic (no toxic signs at twice the lethal dose for PBN), whereas 2,6-difluoro-PBN and M4PO (3,3,5,5-tetramethyl-1-pyrroline-N-oxide) were the most toxic as both cause death at $1 / 8$ of the PBN-equivalent lethal dose [92]. Table 3 shows that non-irritating spin traps have low TEWL $\left(13 \mathrm{~g} / \mathrm{m}^{2} \cdot \mathrm{h}-16 \mathrm{~g} / \mathrm{m}^{2} \cdot \mathrm{h}\right)$, whereas DOXO is a slight irritant with good TEWL $\left(24 \pm 5 \mathrm{~g} / \mathrm{m}^{2} \cdot \mathrm{h}\right)$. Theoretically, a combination of spin traps with non-irritation and high TEWL can be used in skin care formulations. Moreover, Haselof et al. [93] and Janzen [94] have studied the cytotoxicity (the inhibitory concentration at half maximum, IC $50 \mathrm{mM} ; 50 \%$ cell viability) of spin traps on bovine aortic endothelial cells and found that DMPO is least toxic (138.34 $\pm 2.22 \mathrm{mM})$ followed by PBN $(9.37 \pm 0.26 \mathrm{mM})$, but TEMPO is found to be highly cytotoxic (0.72 $\pm 0.05 \mathrm{mM})$. DMPO is least toxic but may not hold trans-epidermal moisturization as it exhibits low TEWL. Comparing all 
properties, PBN has low toxic and provide good TEWL and can be used alone or with DMPO (least toxic but low TEWL) in cosmetic formulations.

Table 3. Types of spin traps.

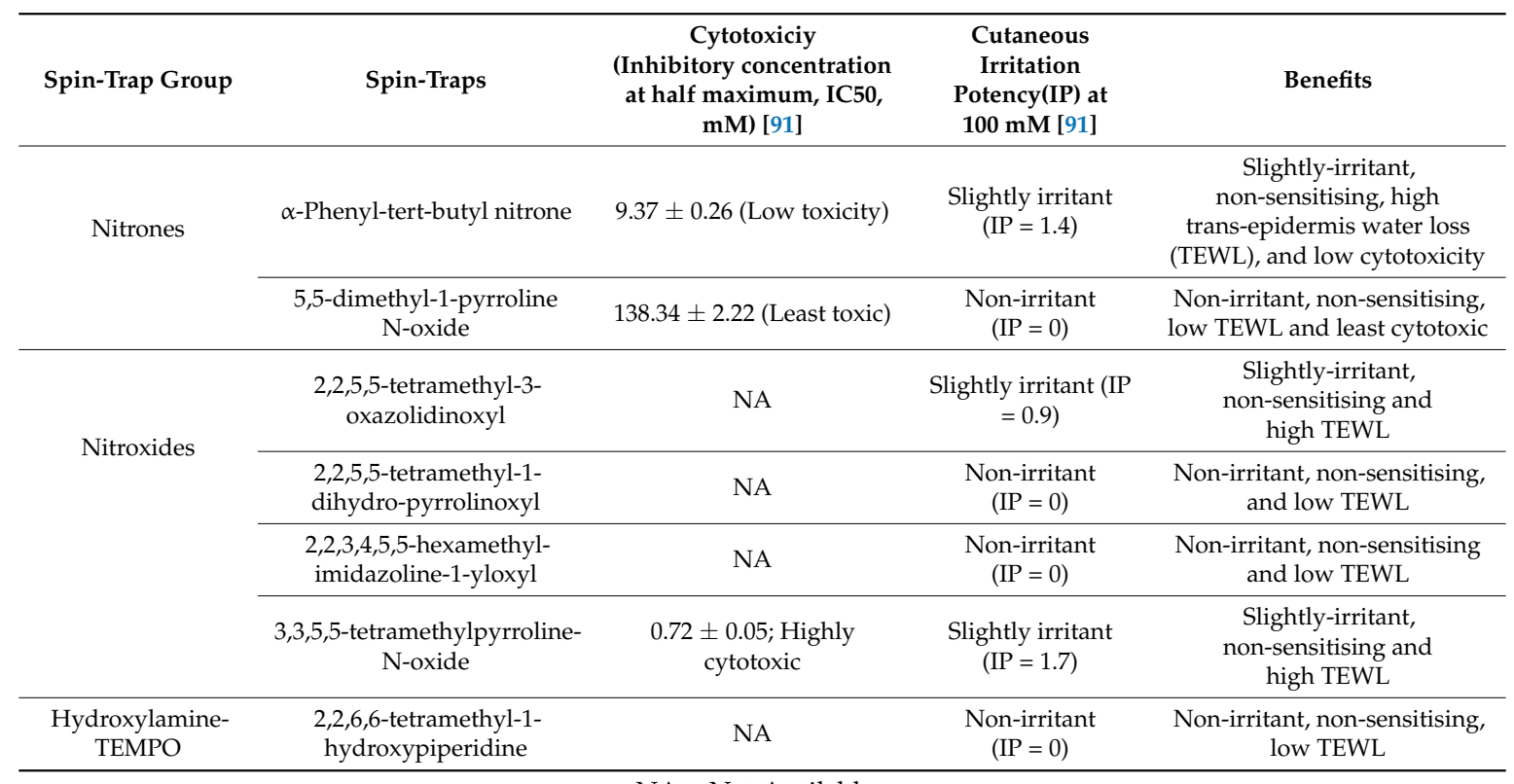

NA = Not Available.

PBN, other nitrone-based and nitroso-based spin traps can ameliorate the cellular dysfunction in tissue partially due to high energy oxygen and hydroxyl free radicals, and enhance recuperation of the tissue. Therefore, PBN is used as an anti-alopecia agent to stimulate cosmetic hair growth [95]. A study by Barclay et al. revealed that PBN exhibited only retardant (not antioxidant) activity during peroxidation of linoleate (in lipids) initiated by lipid-soluble di-tert-butyl hyponitrite or azobis (2-amidino propane hydrochloride) in sodium dodecyl sulphate micelles [96].

In the near future, PBN or other suitable spin traps (along with other actives/antioxidants) may also need to be included in cosmetic products to reduce or stop ROS and other free radicals generated by high frequency - high energy (HFHE) visible light $(\lambda=400-450 \mathrm{~nm})[97,98]$, near-infrared light (NIR) $(\lambda=760-3000 \mathrm{~nm})$ and blue light $(\lambda=450-495 \mathrm{~nm})$. This is important because the free radicals generated by the HFHE visible light can potentially affect 40 skin related genes [98] that can attenuate the healing process leading to weak barrier functions, inflammation and un-even pigmentation to the skin. Additionally, NIR light has been shown to create free radicals [99]. Both HFHE and NIR can produce MMP-1 and MMP-9 leading to aging and degradation of collagen in the skin [98-102]. Moreover, blue-violet light at high doses may also generate free radicals [103]. Blue light is used to treat acne [104], psoriasis [104,105] and AD [106] through ROS production and its short-term use in clinics is found to be safe $[107,108]$. PBN like spin traps can help reduce the effect of prolong exposure of blue light induced free radicals on the (healthy, diseased or old) skin and further reduce the aging effect. This is particularly applicable for our current (modern) lifestyle due to our extensive exposure to digital appliances such as laptop, smart phone, television, etc. Further research is needed to ascertain the effect of prolonged exposure to blue light from optoelectronic appliances on the skin under various conditions (environmental or age-related), in order to develop new spin traps or formulations to enhance the protection of the skin.

Spin traps, lipophilic in nature, can be encapsulated by lipid spherules or vesicles to release into the epidermis and dermis layers [109]. The diffusion constant of these encapsulated systems in the stratum corneum is found to be $<1 \times 10^{-7} \mathrm{~cm}^{2} \cdot \mathrm{s}^{-1}$ [109]. The diffusion coefficient can be varied by varying the composition of vesicles [109]. 
Different molecular weights of sodium hyaluronate are known to transfer biomacromolecules and other actives transdermally [110-113], and can also be used for dermal delivery of other actives including spin traps. Hypothetically, low viscous (less than $300 \mathrm{cPs}$ ) oil-in-water formulations such as serums containing low viscous sodium hyaluronate, medium viscous hydrogels (5000-10,000 cPs) and creams with viscosity ( $>10,000 \mathrm{cPs}$ ) can be used to transfer actives including spin traps to different parts of the skin. For example, low viscous serum containing low molecular weight (MW) sodium hyaluronate $(<50 \mathrm{kDa})$ may transport actives to cell-cell junctions, hydrogels with medium MW sodium hyaluronate (50-300 kDa) will restrict transfer of actives predominantly to epidermis and supply moisturization, and high viscous cream with high MW sodium hyaluronate (>1 MDa) (containing $30-60 \%$ oil phase) can restrict actives to stratum corneum or top skin layers and reduce TEWL due to a high oil phase. Additionally, different weights of sodium hyaluronate may provide moisturization to all skin layers from inside out. With this three-step process, actives with spin traps can provide thorough protection to all levels of the skin structure from inside out. Additionally, chemical enhancers [114] or polymeric hydroethanolic systems [115] can be used for the controlled dermal delivery of spin traps and actives.

In the current global cosmetic market, the spin traps (particularly PBN) are included along with other antioxidants or cosmeceuticals in a few high-end cosmetic products, mostly for the antiaging purposes [116]. The number of antipollution cosmetics has increased by 40\% between 2011 and 2013, which represent a market share of $28 \%$ in the Asia-Pacific region [117]. Anti-pollution cosmetics accounted for $1 \%$ of newly launched beauty products worldwide in 2016, except in Europe where the anti-pollution cosmetic trend is stagnating [117]. This trend of using spin traps in cosmetics shall increase in the next few years. However, the toxicity and regulatory constraints of spin traps need further studies before being included into topical skin-care products to treat skin-indications.

\section{Conclusions}

Pollution from air and sunlight has an adverse effect on the human health, particularly the skin health due to the oxidative stress, which can induce skin diseases such as skin cancer and aging. Different types of antioxidants have been used as preventative actives in skin-care products to scavenge free radicals. However, antioxidants have some limitations, as they can block the normal oxygen in the organs, which is helpful for the skin rejuvenation. Recently, spin traps are being explored to trap ROS before free radicals generate more free radicals in the cascading effect, with PBN being one of the spin-traps used in cosmetic products. Spin traps can specifically scavenge free radicals before the cascading effect and will not scavenge normal oxygen. However, not all spin traps can be used in the topical cosmetic skin-care products currently due to toxicity and regulatory issues.

Acknowledgments: The author sincerely thanks Anthony McMahon for constant encouragement and Nur Hafizah Misran and Ashlea Carroll for correcting the manuscript. The author sincerely wishes to dedicate this article to the (late) Patrick McMahon.

Conflicts of Interest: The author declares no conflict of interest.

\section{References}

1. WHO Website. Available online: http://www.who.int/phe/health_topics/outdoorair/databases/cities/en/ (accessed on 15 December 2017).

2. Beelen, R.; Hoek, G.; van den Brandt, P.A.; Goldbohm, R.A.; Fischer, P.; Schouten, L.J.; Armstrong, B.; Brunekreef, B.R. Long-term exposure to traffic-related air pollution and lung cancer risk. Epidemiology 2008, 19, 702-710. [CrossRef] [PubMed]

3. Castano-Vinyals, G.; Cantor, K.P.; Malats, N.; Tardon, A.; Garcia-Closas, R.; Serra, C.; Carrato, A.; Rothman, N.; Vermeulen, R.; Silverman, D.; et al. Air pollution and risk of urinary bladder cancer in a case-control study in Spain. Occup. Environ. Med. 2008, 65, 56-60. [CrossRef] [PubMed]

4. Kim, K.E.; Cho, D.; Park, H.J. Air pollution and skin diseases: Adverse effects of airborne particulate matter on various skin diseases. Life Sci. 2016, 152, 126-134. [CrossRef] [PubMed] 
5. Rahman, K. Studies on free radicals, antioxidants, and co-factors. Clin. Interv. Aging 2007, 2, 219-236. [PubMed]

6. Lopaczynski, W.; Zeisel, S.H. Antioxidants, programmed cell death, and cancer. Nutr. Res. 2001, $21,295-307$. [CrossRef]

7. Glade, M.J. The role of reactive oxygen species in Health and Disease. Nutrition 2003, 19, 401-403.

8. Oberdörster, G.; Oberdörster, E.; Oberdörster, J. Nanotoxicology: An Emerging Discipline Evolving from Studies of Ultrafine Particles. Environ. Health Perspect. 2005, 113, 823-839.

9. Donaldson, K.; Tran, L.; Jimenez, L.A.; Duffin, R.; Newby, D.E.; Mills, N.; MacNee, W.; Stone, V. Combustion-derived nanoparticles: A review of their toxicology following inhalation exposure. Part. Fibre Toxicol. 2005, 2, 10. [CrossRef] [PubMed]

10. Li, N.; Sioutas, C.; Cho, A.; Schmitz, D.; Misra, C.; Sempf, J.; Wang, M.; Oberley, T.; Froines, J.; Nel, A. Ultrafine particulate pollutants induce oxidative stress and mitochondrial damage. Environ. Health Perspect. 2003, 111, 455-460. [CrossRef] [PubMed]

11. Menichini, E. Urban air pollution by polycyclic aromatic hydrocarbons: Levels and sources of variability. Sci. Total Environ. 1992, 116, 109-135. [CrossRef]

12. Penning, T.M.; Burcynski, M.E.; Hung, C.F.; McCoull, K.D.; Palackal, N.T.; Tsuruda, L.S. Dihydrodiol dehydrogenase and polycyclic aromatic hydrocarbon activation: Generation of reactive and redox active o-quinones. Chem. Res. Toxicol. 1999, 12, 1-18. [CrossRef] [PubMed]

13. Rostan, E.F.; DeBuys, H.V.; Madey, D.L.; Pinnell, S.R. Evidence supporting zinc as an important antioxidant for skin. Int. J. Dermatol. 2002, 41, 606-611. [CrossRef] [PubMed]

14. Lobo, V.; Patil, A.; Phatak, A.; Chandra, N. Free radicals, antioxidants and functional foods: Impact on human health. Pharmacogn. Rev. 2010, 4, 118-126. [CrossRef] [PubMed]

15. Janzen, E.G.; Blackburn, B.J. Detection and identification of short-lived free radicals by electron spin resonance trapping techniques (spin trapping). Photolysis of organolead, -tin, and -mercury compounds. J. Am. Chem. Soc. 1969, 91, 4481-4490. [CrossRef]

16. Mancebo, S.E.; Wang, S.Q. Recognizing the impact of ambient air pollution on skin health. J. Eur. Acad. Dermatol. Venereol. 2015, 29, 2326-2332. [CrossRef] [PubMed]

17. Lademann, J.; Schaefer, H.; Otberg, N.; Teichmann, A.; Blume-Peytavi, U.; Sterry, W. Penetration of microparticles into human skin. Hautarzt 2004, 55, 1117-1119. [CrossRef] [PubMed]

18. Fritsche, E.; Schäfer, C.; Calles, C.; Bernsmann, T.; Bernshausen, T.; Wurm, M.; Hübenthal, U.; Cline, J.E.; Hajimiragha, H.; Schroeder, P.; et al. Lighting up the UV response by identification of the arylhydrocarbon receptor as a cytoplasmic target for ultraviolet B radiation. Proc. Natl. Acad. Sci. USA 2007, 104, 8851-8856. [CrossRef] [PubMed]

19. Jux, B.; Kadow, S.; Esser, C. Langerhans cell maturation and contact hypersensitivity are impaired in aryl hydrocarbon receptor-null mice. J. Immunol. 2009, 182, 6709-6717. [CrossRef] [PubMed]

20. Pan, T.L.; Wang, P.W.; Aljuffali, I.A.; Huang, C.T.; Lee, C.W.; Fang, J.Y. The impact of urban particulate pollution on skin barrier function and the subsequent drug absorption. J. Dermatol. Sci. 2015, 78, 51-60. [CrossRef] [PubMed]

21. Vierkötter, A.; Schikowski, T.; Ranft, U.; Sugiri, D.; Matsui, M.; Krämer, U.; Krutmann, J. Airborne Particle Exposure and Extrinsic Skin Aging. J. Investig. Dermatol. 2010, 130, 2719-2726. [CrossRef] [PubMed]

22. Mak, A.; Tay, S.H. Environmental Factors, Toxicants and Systemic Lupus Erythematosus. Int. J. Mol. Sci. 2014, 15, 16043-16056. [CrossRef] [PubMed]

23. Misery, L.; Loser, K.; Stander, S. Sensitive skin. J. Eur. Acad. Dermatol. Venereol. 2016, 30 (Suppl. 1), 2-8. [CrossRef] [PubMed]

24. Sisignano, M.; Angioni, C.; Ferreiros, N.; Schuh, C.D.; Suo, J.; Schreiber, Y.; Dawes, J.M.; Antunes-Martins, A.; Bennett, D.L.H.; McMahon, S.B.; et al. Synthesis of lipid mediators during UVB-induced inflammatory hyperalgesia in rats and mice. PLoS ONE 2013, 8, e81228. [CrossRef] [PubMed]

25. Tamagawa-Mineoka, R.; Ueta, M.; Katoh, N. TLR3 and Inflammatory Skin Diseases: From Environmental Factors to Molecular Opportunities. In Skin Stress Response Pathways; Springer: Berlin, Germany, 2016; pp. 235-249.

26. Otsuka, A.; Nomura, T.; Rerknimitr, P.; Seidel, J.A.; Honda, T.; Kabashima, K. The interplay between genetic and environmental factors in the pathogenesis of atopic dermatitis. Immunol. Rev. 2017, 278, $246-262$. [CrossRef] [PubMed]

27. Volkovova, K.; Bilanicova, D.; Bartonova, A.; Letašiová, S.; Dusinska, M. Associations between environmental factors and incidence of cutaneous melanoma. Rev. Environ. Health 2012, 11 (Suppl. 1), S12. 
28. Matsumu, Y.; Ananthaswamy, H.N. Toxic effects of ultraviolet radiation on the skin. Toxicol. Appl. Pharmacol. 2004, 195, 298-308. [CrossRef] [PubMed]

29. Hölzle, E.; Hönigsmann, H. UV-radiation-sources, wavelength, environment. J. Dtsch. Dermatol. Ges. 2005, 3 (Suppl. 2), S3-S10. [CrossRef] [PubMed]

30. Madronich, S.; McKenzie, R.L.; Björn, L.O.; Caldwell, M.M. Changes in biologically active ultraviolet radiation reaching the Earth's surface. J. Photochem. Photobiol. B 1998, 46, 5-19. [CrossRef]

31. Situm, M.; Buljan, M.; Bulić, S.O.; Simić, D. The mechanisms of UV radiation in the development of malignant melanoma. Coll. Antropol. 2007, 1, 13-16.

32. Garibyan, L.; Fisher, D.E. How sunlight causes melanoma. Curr. Oncol. Rep. 2010, 12, 319-326. [CrossRef] [PubMed]

33. Afanas'ev, I.B. Signaling by reactive oxygen and nitrogen species in skin diseases. Curr. Drug Metab. 2010, 11, 409-414. [CrossRef] [PubMed]

34. He, Y.Y.; Huang, J.L.; Sik, R.H.; Liu, J.; Waalkes, M.P.; Chignell, C.D. Expression profiling of human keratinocyte response to ultraviolet A: Implications in apoptosis. J. Investig. Dermatol. 2004, 122, 533-543. [CrossRef] [PubMed]

35. Hoffmann, K.; Kaspar, K.; Altmeyer, P.; Gambichler, T. UV transmission measurements of small skin specimens with special quartz cuvettes. Dermatology 2000, 201, 307-311. [CrossRef] [PubMed]

36. Davies, H.; Bignell, G.R.; Cox, C. Mutations of the BRAF gene in human cancer. Nature 2002, 417, 949-954. [CrossRef] [PubMed]

37. Parrish, J.A.; Kurt, F.; Jaenicke, R.; Rox, A. Erythema and melanogenesis action spectra of normal human skin. Photochem. Photobiol. 1982, 36, 187-191. [CrossRef] [PubMed]

38. Eskandarpour, M.; Hashemi, J.; Kanter, L. High gene mutation rate may contribute to hereditary skin cancers. J. Natl. Cancer Inst. 2003, 95, 790-798. [CrossRef] [PubMed]

39. Li, G.; Ho, V.C.; Trotter, M.J.; Horsman, D.E.; Tron, V.A. Mutation in metastatic melanomas and primary melanomas from sun-exposed and sun-protected sites. J. Eur. Acad. Dermatol. Venereol. 1995, 4, 48-53. [CrossRef]

40. Goodsell, D.S. The molecular perspective: Ultraviolet light and pyrimidine dimers. Oncologist 2001, 6, 298-299. [CrossRef] [PubMed]

41. Friedberg, E.C.; Walker, G.C.; Siede, W.; Wood, R.D.; Schultz, R.A.; Ellenberger, T. DNA Repair and Mutagenesis, 2nd ed.; ASM Press: Washington, DC, USA, 2006; pp. 1118-1120.

42. Whitmore, S.E.; Potten, C.S.; Chadwick, C.A.; Strickland, P.T.; Morison, W.L. Effect of photoreactivating light on UV radiation-induced alterations in human skin. Photodermatol. Photoimmunol. Photomed. 2001, 17, 213-217. [CrossRef] [PubMed]

43. Matsunaga, T.; Hatakeyama, Y.; Ohta, M.; Mori, T.; Nikaido, O. Establishment and characterization of a monoclonal-antibody recognising the Dewarisomers of (6-4) photoproducts. Photochem. Photobiol. 1993, 57, 934-940. [CrossRef] [PubMed]

44. Mitchell, D.L.; Rosenstein, B.S. The use of specific radioimmunoassays to determine action spectra for the photolysis of (6-4) photoproducts. Photochem. Photobiol. 1987, 45, 781-786. [CrossRef] [PubMed]

45. Baier, J.; Maisch, T.; Maier, M.; Engel, E.; Landthaler, M.; Bäumler, W. Singlet oxygen generation by UVA light exposure of endogenous photosensitizes. Biophys. J. 2006, 91, 1452-1459. [CrossRef] [PubMed]

46. Sohal, R.S.; Weindruch, R. Oxidative stress, caloric restriction, and aging. Science 1996, 273, 59-63. [CrossRef] [PubMed]

47. Hanson, K.M.; Simon, J.D. Epidermal trans-urocanic acid and the UV-A-induced photoaging of the skin. Proc. Natl. Acad. Sci. USA 1998, 95, 10576-10578. [CrossRef] [PubMed]

48. Albro, P.W.; Bilski, P.; Corbett, J.T.; Schroeder, J.L.; Chignell, C.F. Photochemical reactions and phototoxicity of sterols: Novel self-perpetuating mechanisms for lipid photooxidation. Photochem. Photobiol. 1997, 66, 316-325. [CrossRef] [PubMed]

49. Wondrak, G.T.; Roberts, M.J.; Jacobson, M.K.; Jacobson, E.L. 3-Hydroxypyridine Chromophores Are Endogenous Sensitizers of Photooxidative Stress in Human Skin Cells. J. Biol. Chem. 2004, 279, 30009-30020. [CrossRef] [PubMed]

50. Wenczl, E.; van der Schans, G.P.; Roza, L.; Kolb, R.M.; Timmerman, A.J.; Smit, N.P.M.; Pavel, S.; Schothorst, A.A. (Pheo)Melanin Photosensitizes UVA-Induced DNA Damage in Cultured Human Melanocytes. J. Investig. Dermatol. 1998, 111, 678-682. [CrossRef] [PubMed] 
51. Babu, V.; Joshi, P.C. Tryptophan as an endogenous photosensitizer to elicit harmful effects of ultraviolet B. Indian J. Biochem. Biophys. 1992, 29, 296-298. [PubMed]

52. Defedericis, H.C.; Patrzyc, H.B.; Rajecki, M.J.; Budzinski, E.E.; Lijima, H.; Dawidzik, J.B.; Evans, M.S.; Greene, K.E.; Box, H.C. Singlet oxygen-induced DNA damage. Radiat. Res. 2006, 165, 445-451. [CrossRef] [PubMed]

53. Mena, S.; Ortega, A.; Estrela, J.M. Oxidative stress in environmental-induced carcinogenesis. Mutat. Res. 2009, 674, 36-44. [CrossRef] [PubMed]

54. Ribeiro, D.T.; Madzak, C.; Sarasinm, A.; DI Mascio, P.; Sies, H.; Menckm, C.F.M. Singlet oxygen induced DNA damage and mutagenicity in a single-stranded SV40-based shuttle vector. Photochem. Photobiol. 1992, 55, 39-45. [CrossRef] [PubMed]

55. Jia, L.; Shafirovich, V.; Shapiro, R.; Geacintov, N.E.; Broyde, S. Spiroimino dihydantoin lesions derived from guanine oxidation structures, energetics, and functional implications. Biochemistry 2005, 44 (Suppl. 16), 6043-6051. [CrossRef] [PubMed]

56. Mustafa, M.G. Biochemical basis of ozone toxicity. Free Radic. Biol. Med. 1990, 9, 245-265. [CrossRef]

57. Gruber, J.V.; Tay, A.; Holtz, R. Protecting the skin against ozone. J. Cosmet. Sci. 2005, 56, 348-349.

58. Sitch, S.; Cox, P.M.; Collins, W.J.; Huntingford, C. Indirect radiative forcing of climate change through ozone effects on the land-carbon sink. Nature 2007, 448, 791-794. [CrossRef] [PubMed]

59. Pryor, W.C. Free radical reactions in biology: Initiation of lipid autoxidation by ozone and nitrogen dioxide. Environ. Health Perspect. 1979, 16, 180-181.

60. Han, S.J.; Kwak, M.K.; Han, D.H.; Kim, S.H.; Jang, A.S. Ozone Exposure Suppresses Proliferative Response in Mice Skin. Korean J. Intern. Med. 2012, 27, 360-362. [CrossRef] [PubMed]

61. Thiele, J.J.; Traber, M.G.; Podda, M.; Tsang, K.; Cross, C.E.; Packer, L. Ozone depletes tocopherols and tocotrienols topically applied to murine skin. FEBS Lett. 1997, 401, 167-170. [CrossRef]

62. Fortino, V.; Maioli, E.; Torricelli, C.; Davis, P.; Valacchi, G. Cutaneous MMPs are differently modulated by environmental stressors in old and young mice. Toxicol. Lett. 2007, 173, 73-79. [CrossRef] [PubMed]

63. Thiele, J.J.; Traber, M.G.; Tsang, K.; Cross, C.E.; Packer, L. In vivo exposure to ozone depletes vitamins C and E and induces lipid peroxidation in epidermal layers of murine skin. Free Radic. Biol. Med. 1997, 23, 385-391. [CrossRef]

64. Thiele, J.J.; Traber, M.G.; Polefka, T.G.; Cross, C.E.; Packer, L. Ozone-exposure depletes vitamin E and induces lipid peroxidation in murine stratum corneum. J. Investig. Dermatol. 1997, 108, 753-757. [CrossRef] [PubMed]

65. Valacchi, G.; Weber, S.U.; Luu, C.; Cross, C.E.; Packer, L. Ozone potentiates vitamin E depletion by ultraviolet radiation in the murine stratum corneum. FEBS Lett. 2000, 466, 165-168. [CrossRef]

66. Pryor, W.C.; Church, D.F. The reaction of ozone with unsaturated fatty acids: Aldehydes and hydrogen peroxide as mediators of ozone toxicity. In Oxidative Damage and Repair: Chemical, Biological and Medical Aspects; Davies, K.J.A., Ed.; Pergamon Press: New York, NY, USA, 1991; pp. 496-504.

67. Valacchi, G.; van der Vliet, A.; Schock, B.C.; Okamoto, T.; Obermuller-Jevic, U.; Cross, C.E.; Packer, L. Ozone exposure activates oxidative stress responses in murine skin. Toxicology 2002, 179, 163-170. [CrossRef]

68. He, Q.C.; Tavakkol, A.; Wietecha, K.; Begum-Gafur, R.; Ansari, S.A.; Polefka, T. Effects of environmentally realistic levels of ozone on stratum corneum function. Int. J. Cosmet. Sci. 2006, 28, 349-357. [CrossRef] [PubMed]

69. Valacchi, G.; Pagnin, E.; Okamoto, T.; Corbacho, A.M.; Olano, E.; Davis, P.A.; van der Vliet, A.; Packer, L.; Cross, C.E. Induction of stress proteins and MMP-9 by 0.8 ppm of ozone in murine skin. Biochem. Biophys. Res. Commun. 2003, 305, 741-746. [CrossRef]

70. Shindo, Y.; Witt, E.; Han, D.; Epstein, W.; Packer, L. Enzymic and non-enzymic antioxidants in epidermis and dermis of human skin. J. Investig. Dermatol. 1994, 102, 122-124. [CrossRef] [PubMed]

71. Murray, J.C.; Burch, J.A.; Streilein, R.D.; Iannacchione, M.A.; Hall, R.P.; Pinnell, S.R. A topical antioxidant solution containing vitamins $\mathrm{C}$ and $\mathrm{E}$ stabilized by ferulic acid provides protection for human skin against damage caused by ultraviolet irradiation. J. Am. Acad. Dermatol. 2008, 59, 418-425. [CrossRef] [PubMed]

72. Lin, F.H.; Lin, J.Y.; Gupta, R.D.; Tournas, J.A.; Burch, J.A.; Selim, M.A.; Monteiro-Riviere, N.A.; Grichnik, J.M.; Zielinski, J.; Pinnell, S.R. Ferulic acid stabilizes a solution of vitamins $\mathrm{C}$ and $\mathrm{E}$ and doubles its photoprotection of skin. J. Investig. Dermatol. 2005, 125, 826-832. [CrossRef] [PubMed]

73. Afaq, F.; Zaid, M.A.; Pelle, E.; Khan, N.; Syed, D.N.; Matsui, M.S.; Maes, D.; Mukhta, H. Aryl Hydrocarbon Receptor Is an Ozone Sensor in Human Skin. J. Investig. Dermatol. 2009, 129, 2396-2403. [CrossRef] [PubMed] 
74. Thiele, J.J.; Podda, M.; Packer, L. Tropospheric ozone: An emerging environmental stress to skin. Biol. Chem. 1997, 378, 1299-1305. [PubMed]

75. Fabbrocini, G.; Triassi, M.; Mauriello, M.C.; Torre, G.; Annunziata, M.C.; De Vita, V.; Pastore, F.; D'Arco, V.; Monfrecola, G. Epidemiology of Skin Cancer: Role of Some Environmental Factors. Cancers 2010, 2, 1980-1989. [CrossRef] [PubMed]

76. Valacchi, G.; Pecorelli, A.; Cervellati, F.; Cervellati, C.; Maioli, E. Cutaneous responses to environmental stressors. Ann. N. Y. Acad. Sci. 2012, 1271, 75-81. [CrossRef] [PubMed]

77. Kammeyer, A.; Luiten, R.M. Oxidation events and skin aging. Ageing Res. Rev. 2015, 21, 16-29. [CrossRef] [PubMed]

78. Birch-Machin, M.A.; Bowman, A. Oxidative stress and ageing. Br. J. Dermatol. 2016, 175 (Suppl. 2), $26-29$. [CrossRef] [PubMed]

79. Naidoo, K.; Birch-Machin, M.A. Oxidative Stress and Ageing: The Influence of Environmental Pollution, Sunlight and Diet on Skin. Cosmetics 2017, 4, 4. [CrossRef]

80. Niki, E. Antioxidant defenses in eukaryotic cells. In Free Radicals: From Basic Science to Medicine; Poli, G., Albano, E., Dianzani, M.U., Eds.; Birkhauser Verlag: Basel, Switzerland, 1993; pp. 365-373.

81. Makino, E.; Vega, V.; Kadoya, K.; Fleck, T.; Mehta, R. A novel blend of antioxidants minimizes UV-induced DNA damage markers in human skin. J. Am. Acad. Dermatol. 2016, 74 (Suppl. 1), AB11.

82. Valacchi, G.; Sticozzi, C.; Chen, N.; Demaude, J.; Krol, Y.; Oresajo, C. Antioxidant mixtures protect against ozone induced damage in human reconstructed skin model. J. Am. Acad. Dermatol. 2016, 74 (Suppl. 1), AB31.

83. Valacchi, G.; Sticozzi, C.; Chen, N.; Krol, Y.; Oresajo, C. Antioxidants prevent ozone-induced oxidative damage in human keratinocytes. J. Am. Acad. Dermatol. 2015, 72 (Suppl. 1), AB28.

84. Rosen, G.M.; Finkelstein, E. Use of spin traps in biological systems. Adv. Free Radic. Biol. Med. 1985, 1, 345-375. [CrossRef]

85. Marchand, V.; Charlier, N.; Verrax, J.; Buc-Calderon, P.; Levêque, P.; Gallez, B. Use of a cocktail of spin traps for fingerprinting large range of free radicals in biological systems. PLoS ONE 2017, 12, e0172998. [CrossRef] [PubMed]

86. Floyd, R.A.; Hensley, K.; Forster, M.J.; Kelleher-Andersson, J.A.; Wood, P.L. Nitrones, their value as therapeutics and probes to understand aging. Mech. Ageing Dev. 2002, 123, 1021-1031. [CrossRef]

87. Floyd, R.A.; Hensley, K.; Forster, M.J.; Kelleher-Andersson, J.A.; Wood, P.L. Nitrones as neuroprotectants and antiaging drugs. Ann. N. Y. Acad. Sci. 2002, 959, 321-329. [CrossRef] [PubMed]

88. Floyd, R.A.; Hensley, K. Nitrone inhibition of age-associated oxidative damage. Ann. N. Y. Acad. Sci. 2000, 899, 222-237. [CrossRef] [PubMed]

89. Floyd, R.A. Antioxidants, oxidative stress, and degenerative neurological disorders. Proc. Soc. Exp. Biol. Med. 1999, 222, 236-245. [CrossRef] [PubMed]

90. Ali, M.A.; Konishi, T. Enhancement of hydroxyl radical generation in the Fenton reaction by alpha-hydroxy acid. Biochem. Mol. Biol. Int. 1998, 46, 137-145. [CrossRef] [PubMed]

91. Fuchs, J.; Groth, N.; Herrling, T. Cutaneous tolerance to nitroxide free radicals and nitrone spin traps in the guinea pig. Toxicology 1998, 126, 33-40. [CrossRef]

92. Fuchs, J.; Groth, N.; Herrling, T. Biological magnetic resonance. In In-Vivo EPR (ESR); Springer: New York, NY, USA, 2003; Volume 18, pp. 483-513.

93. Haselof, R.F.; Mertsch, K.; Rohde, A.; Baeger, A.; Grigor'ev, I.A.; Blasig, I.E. Cytotoxicity of spin trapping compounds. FEBS Lett. 1997, 418, 73-75. [CrossRef]

94. Janzen, E.G.; Poyer, J.L.; Schaefer, C.F.; Downs, P.E.; DuBose, C.M. Biological spin trapping. II. Toxicity of nitrone spin traps: Dose-ranging in the rat. Biochem. Biophys. Methods 1995, 30, 239-247. [CrossRef]

95. Proctor, P.H. Topical Spin Trap Composition and Method. U.S. Patent 5,723,502, 3 March 1998.

96. Barclay, L.R.C.; Dakin, K.A.; Khor, J.A.Y. The autoxidation of thiol aminoacids and ascorbate and their cooperative effects as antioxidants with trolox in micelles and lipid bilayers. Res. Chem. Intermed. 1995, 21, 467-488. [CrossRef]

97. Zastrow, L.; Groth, N.; Klein, F.; Kockott, D.; Lademann, J.; Ferrero, L. Detection and identification of free radicals generated by UV and visible light in Ex Vivo human skin. IFSCC Mag. 2008, 11, 297-315.

98. Liebel, F.; Kaur, S.; Ruvolo, E.; Kollias, N.; Southall, M.D. Irradiation of skin with visible light induces reactive oxygen species and matrix-degrading enzymes. J. Investig. Dermatol. 2012, 132, 1901-1907. [CrossRef] [PubMed] 
99. Yoon, H.S.; Kim, Y.K.; Matsui, M.; Chung, J.H. Possible role of infrared or heat in sun-induced changes of dermis of human skin in vivo. J. Dermatol. Sci. 2012, 66, 76-78. [CrossRef] [PubMed]

100. Schroeder, P.; Lademann, J.; Darvin, M.E.; Stege, H.; Marks, C.; Bruhnke, S.; Krutmann, J. Infrared radiation-induced matrix metalloproteinase in human skin: Implications for protection. J. Investig. Dermatol. 2008, 128, 2491-2497. [CrossRef] [PubMed]

101. Robert, C.; Bonnet, M.; Marques, S.; Numa, M.; Doucet, O. Low to moderate doses of infrared A irradiation impair extracellular matrix homeostasis of the skin and contribute to skin photodamage. Skin Pharmacol. Physiol. 2015, 28, 196-204. [CrossRef] [PubMed]

102. Cho, S.; Lee, M.J.; Kim, M.S.; Lee, S.; Kim, Y.K.; Lee, D.H.; Lee, C.W.; Cho, K.H.; Chung, J.H. Infrared plus visible light and heat from natural sunlight participate in the expression of MMPs and type I procollagen as well as infiltration of inflammatory cell in human skin in vivo. J. Dermatol. Sci. 2008, 50, 123-133. [CrossRef] [PubMed]

103. Vandersee, S.; Beyer, M.; Lademann, J.; Darvin, M.E. Blue-Violet Light Irradiation Dose Dependently Decreases Carotenoids in Human Skin, Which Indicates the Generation of Free Radicals. Oxid. Med. Cell. Longev. 2015, 2015, 579675. [CrossRef] [PubMed]

104. Wheeland, R.G.; Dhawan, S. Evaluation of self-treatment of mild-to-moderate facial acne with a blue light treatment system. J. Drugs Dermatol. 2011, 10, 596-602. [PubMed]

105. Weinstabl, A.; Hoff-Lesch, S.; Merk, H.F.; von Felbert, V. Prospective randomized study on the efficacy of blue light in the treatment of psoriasis vulgaris. Dermatology 2011, 223, 251-259. [CrossRef] [PubMed]

106. Kleinpenning, M.M.; Otero, M.E.; van Erp, P.E.J.; Gerritsen, M.J.P.; van de Kerkhof, P.C.M. Efficacy of blue light vs. red light in the treatment of psoriasis: A double-blind, randomized comparative study. J. Eur. Acad. Dermatol. Venereol. 2012, 26, 219-225. [CrossRef] [PubMed]

107. Becker, D.; Langer, E.; Seemann, M.; Seemann, G.; Fell, I.; Saloga, J.; Grabbe, S.; von Stebut, E. Clinical efficacy of blue light full body irradiation as treatment option for severe atopic dermatitis. PLoS ONE 2011, 6, e20566. [CrossRef] [PubMed]

108. Kleinpenning, M.M.; Smits, T.; Frunt, M.H.; van Erp, P.E.; van de Kerkhof, P.C.; Gerritsen, R.M. Clinical and histological effects of blue light on normal skin. Photodermatol. Photoimmunol. Photomed. 2010, 26, 16-21. [CrossRef] [PubMed]

109. Ribier, A.L.; Nguyen, Q.L.; Simonnet, J.T.; Boussouira, B. Use of a Spin Trap in a Cosmetic or Dermatological Composition. U.S. Patent 5569663 A, 29 October 1996.

110. Witting, M.; Boreham, A.; Brodwolf, R.; Vávrová, K.; Alexiev, U.; Friess, W.; Hedtrich, S. Interactions of Hyaluronic Acid with the Skin and Implications for the Dermal Delivery of Biomacromolecules. Mol. Pharm. 2015, 12, 1391-1401. [CrossRef] [PubMed]

111. Son, S.U.; Lim, J.W.; Kang, T.; Jung, J.; Lim, E.K. Hyaluronan-Based Nanohydrogels as Effective Carriers for Transdermal Delivery of Lipophilic Agents: Towards Transdermal Drug Administration in Neurological Disorders. Nanomaterials 2017, 7, 427. [CrossRef] [PubMed]

112. Brown, M.B.; Forbes, B.; Martin, G.P. The use of hyaluronan in topical drug delivery. In Hyaluronan: Biomedical, Medical and Clinical Aspects; Kennedy, J., Phillips, G.O., Williams, P.A., Hascall, V., Eds.; Woodhead Publishers: Cambridge, UK, 2002; pp. 249-256.

113. Brown, M.B.; Martin, G.P. Comparison of the effect of hyaluronan and other polysaccharides on drug skin partitioning. Int. J. Pharm. 2001, 225, 113-121. [CrossRef]

114. Sawant, P.D.; Luu, D.; Ye, R.; Buchta, R. Drug release from hydroethanolic gels. Effect of drug's lipophilicity $(\log \mathrm{P})$, polymer-drug interactions and solvent lipophilicity. Int. J. Pharm. 2010, 396, 45-52. [CrossRef] [PubMed]

115. Kang, L.; Sawant, P.D.; Liu, X.Y.; Ho, P.C.L.; Chan, Y.W.; Chan, S.Y. SMGA Gels for the skin permeation of haloperidol. J. Control. Release 2005, 106, 88-98. [CrossRef] [PubMed]

116. Truth Aging Website. Available online: https://www.truthinaging.com/review/spin-trap-what-is-it (accessed on 15 December 2017).

117. Mintel Website. Available online: http://www.mintel.com/press-centre/beauty-and-personal-care/antipollution-claims-on-beauty-products-in-asia-pacific-grow-by-40-in-two-years (accessed on 15 December 2017).

(C) 2018 by the author. Licensee MDPI, Basel, Switzerland. This article is an open access article distributed under the terms and conditions of the Creative Commons Attribution (CC BY) license (http:/ / creativecommons.org/licenses/by/4.0/). 